\title{
The Medium of Instruction in a Multicultural Classroom: Teachers' Perspectives in the Eastern Cape Province of South Africa
}

\author{
Matshikiza Spokazi, Simon Luggya and Magdaline Tanga* \\ Faculty of Education, University of Fort Hare, South Africa \\ https:/ / orcid.org/0000-0002-7493-7758 \\ https://orcid.org/0000-0003-0966-5896 \\ https://orcid.org/0000-0002-8016-8094
}

\begin{abstract}
The South African Government has instituted a policy of multicultural education (ME) to ensure inclusivity and equal learning opportunities for all learners. This paper aimed to explore teachers' perspectives on the medium of instruction in a multicultural classroom. The paper was extracted from a thesis that examined multiculturalism in selected schools in South Africa. A sample of 18 participants was purposively selected from two urban schools that have learners from different socio-cultural backgrounds in the Eastern Cape. The paper used the interpretive paradigm, which aligns with the qualitative approach. Data were analyzed thematically. The findings revealed that as a universal language, most participants preferred using English in the classroom. However, they sometimes code-switch to IsiXhosa and/or Afrikaans (two of the 11 official languages in South Africa) if the need arises. The participants also revealed attempts at balancing the use of English with learners' first language, mostly during breaks, sporting, and cultural events, but they admitted this does not equal ME. Finally, the participants indicated that preference to teach in English was due to its universalism. Consequently, African languages have become receptors and not creators of knowledge. The paper concludes that despite the ME policy, teachers are not keen to practice it because of a lack of skills. It is recommended that the country be zoned into language areas and teachers be taught in at least two dominant languages of each region, excluding the English language, to ensure equal educational opportunities.
\end{abstract}

Keywords: diversity; learners; multicultural; multicultural education; multilingual

* Corresponding author: Magdaline Tanga; Email: MTanga@ufh.ac.za 


\section{Introduction}

The outcome of any educational institution solely depends on the established policies of the country it is in. In recent years, the established educational policies in South Africa have given birth to a more inclusive educational approach. The transformation to a more inclusive and accommodating schooling system was mainly paved by the constitutional reforms of 1996. The primary aim of the 1996 Constitution was to create a nation, the education system included, that upholds the principles of equality, justice, and non-racism (Bitzer \& Botha, 2011). These fundamental changes created the platform for appreciating diversity in the context of South Africa. Similarly, the South African Schools Act (SASA) (Act 84 of 1996) aimed at redressing the past educational injustices and discriminative policies and practices of the apartheid regime. Thus, an attempt was made to transform the education system to ensure that it creates a platform for the principles of fair opportunity and equality. This led to the admission of learners from poor socioeconomic and other racial backgrounds to previously whites-only schools known as "Model C" schools. Most former Model C schools in South Africa have undergone a serious transformation to accommodate and offer exceptional facilities and high academic standards, which explains the learner exodus from public schools to these schools since the early 1990s. The desegregation called for curriculum content and approaches that reflect the diversity of the country and inclusivity, which gave rise to Multicultural Education (ME). The ME approach creates equal educational opportunities for school learners from diverse backgrounds. According to Banks (2008, p. 38), "ME was created to provide educators with a platform for working with such diverse school populations and achieving justice within societies marked by inequalities based on language, gender, socioeconomic status, or religion."

Schools had to address the learning needs of a diverse population of learners. Hooijer and Fourie (2009) observed that the change in the composition of learners in former racial schools raised concerns about the capacity of schools to cope with multiculturalism in the classroom. In trying to address this situation, the Pan South African Language Board (PANSALB), according to Ohyama (2018), was created in 1995 to promote multilingualism. It established a system that adopts the home language of the region as the language of instruction up to Grade 3. As stated in Section 29 of the South African Constitution (Bill of Rights): "Everyone has the right to receive education in the official languages of their choice in public educational institutions" (Republic of South Africa, 1996). Consequently, learners should be taught in the language of their choice. Furthermore, in a multicultural classroom, teachers should be multilingual to teach learners from diverse sociocultural backgrounds (Banks \& Banks, 2019). This is because a multilingual classroom comprises learners with a variety of first languages (Georgieva \& Shehu, 2017).

To achieve justice within the educational system of South Africa, educators were provided with a multilingual approach to work with diverse school populations (Banks \& Banks, 2019). In this regard, the teachers have to be multilingual to be able to translate where the learners do not understand. Despite all these efforts by the government, there are issues of mismatch in $\mathrm{ME}$ classrooms regarding the 
medium of instruction. Ohyama (2018) maintained that South Africa has developed goals for multilingualism. However, the medium of instruction that should be used in the classroom may be challenging given that South Africa has 11 official languages. Kretzer (2019) was of the view that most multilingual schools in South Africa choose as medium of instruction English or Afrikaans and not an African language. Teachers may only code-switch to clarify a difficult concept. Presumably, African languages are not given priority to facilitate teaching and learning, which is contrary to Basic Education Minister Angie Motshekga's recent claim (BusinessTech, 2019). Seemingly, most teachers might find it difficult to acquire the basic language skills of all 11 official languages to be able to facilitate teaching and learning. Therefore, this paper aimed to explore South African teachers' perspectives on the medium of instruction in a multicultural classroom. The next section is the literature review and is followed by a discussion of the research methods. The paper then moves to the presentation of findings and ends with the conclusions and recommendations of the study.

\section{Literature Review}

Teachers in most countries in the world have been confronted with learners coming from different socio-cultural backgrounds, which presents the challenge of delivering curriculum content in ways that respect the education rights of all. Consequently, these countries have had to grapple with the issue of satisfying all learners by offering them equal education opportunities. Some of the countries have had to struggle with pieces of legislation to balance these educational opportunities. For example, in Australia, the recognition of indigenous culture and languages was made feasible by particular legal fights, which include a series of fundamental legal struggles (Price, 2012). Before this recognition, according to Holm and Zilliacus (2009), Australian educational policies for indigenous culture and language support were lacking the comprehensive aspect of acknowledging language rights.

Wright et al. (2012, pp. 8-9) indicated that "ME in Australia focuses on the following aspects:

$>$ Providing precise teaching programmes of English as a second language for Immigrants and indigenous children and adults;

$>$ First language maintenance for immigrant and indigenous children or mother tongue maintenance;

$>$ Teaching of community/heritage languages;

$>$ Inserting different cultural views among all subject areas of the curriculum, such as history, geography, and citizenship studies; and

$>$ Parent participation and comprehensive rejection of adverse and racist stereotyping of minority populations".

The above constitutes the language policy of Australian multiculturalism.

Canada is one of the countries with a good policy on multiculturalism, especially given its bilingual character. Cultural and linguistic diversity is integrated into its description of national identity, and it has a compulsory national policy of multiculturalism (Howe, 2014). However, there has been a controversy 
surrounding the choice of language for instruction in the school system (Syed, 2010). French has been commonly utilized in Eastern Canada, especially in Quebec and Montreal, whereas English has been commonly utilized in Western Canada (Bianco, 2016). This is an indication that the medium of instruction in a multicultural classroom has been an issue in different countries.

Bianco (2016) argued that the language issue is one of the focal issues within ME in many countries in Africa. This is partially due to how it has been shaped by both conservative and progressive administrations in many countries (Kamp \& Masouri, 2010). Furthermore, research has revealed that the multilingual abilities of African-language speakers are often measured against their proficiency in English only, and this compromises their rich linguistic repertoire (Nomlomo \& Katiya, 2018). Therefore, it is clear that there are controversies regarding language use by teachers in multicultural classrooms. Most teachers find themselves in situations where they need to mediate learning in ways that are contrary to their training or teach in a language and environment in which they are not comfortable because of ME (Meier \& Hartell, 2009).

In South Africa, the Minister of Education and Training announced in 2008 that all schools should commit to providing four hours of lessons in English for most indigenous learners, with the rest of the hours being utilized to teach learners in their first language (Portera, 2010). However, according to Portera (2010), there have been growing concerns about the use of South African languages as media of instruction in schools. Hooijer and Fourie (2009) averred that teachers have argued that teaching in multilingual classrooms is challenging because of the diverse backgrounds, and that they thus need support. Wright (2018) held another view, that there is a need for better educated, trained, and well-motivated language teachers. However, the question is whether being well educated in one language makes one a good teacher in a multicultural classroom. Most classrooms in South African public schools are comprised of learners from a variety of backgrounds who speak different languages and have different educational needs. Meier and Hartell (2009) noted that increasing cultural diversity in educational institutions necessitates improved abilities in teaching and managing diverse learners. The desegregation of schools without considering teachers as facilitators of the public policies heightens tension and prejudices (Du Toit, 1995). The gap between theory and practice in ME, which has outpaced development in practice, has been highlighted by Gay (1992). Without considering their potential, teachers are expected to effectively implement all the designed policies and curriculum transformation. Mickelson and Nkomo (2012) noted teachers' varying challenges with multicultural teaching. Therefore, educators have been seen dealing with classroom diversity for which they may not have been professionally prepared (Robinson, 2003).

Most South African teachers received their training within a mono-cultural context in which education was provided along racial lines (Husén \& Opper, 2014). As such, they were not adequately prepared to teach in a variety of languages and are therefore compelled to utilize their second language. Regardless of the context in which teachers are trained, most find themselves in 
difficult situations of trying to apply the policy of ME. Therefore, there might be some contradictions regarding the right language to use in a multicultural classroom. As Vandeyar (2010, p. 350, as cited in Nieto, 2002) aptly demonstrated, "the languages are spoken by students, which are eventually spoken at school, are resources because didactic cultures are based on the previous understanding and the training learners have had over the years in their home language." According to Nieto (2009), the primary responsibility of teachers is to accept the language assimilation of their students. On the other hand, Rubagumya (2010) indicated that education in the colonial language is culturally alienating. Therefore, the teachers' attitudes, belief systems, ethnic groups, cultural values, and language are important to facilitate teaching and learning. The overview of the literature shows that many countries confront challenges regarding providing instructions in a multicultural environment, especially given the training provided to teachers in a monolingual setting.

Many governments have instituted policies to overcome challenges associated with ME and to provide equal education opportunities to all learners from different socio-cultural backgrounds. Although many studies have been conducted on multiculturalism around the world and in South Africa, there is a dearth of literature on the medium of instruction in a multicultural classroom, especially from the perspectives of teachers. Despite government policies and the school Curriculum and Assessment Policy Statement that promote inclusivity and respect for diverse cultures and training, the implementation of multilingualism in classrooms still needs proper interrogation. There have been complaints from learners, teachers, and stakeholders concerning the medium of instruction used in classrooms. Learners have complained that they were not comfortable with the language of instruction and thus felt excluded during teaching, whilst teachers have complained of not knowing multiple languages. Therefore, this paper interrogates $\mathrm{ME}$ and gauges the perspectives of teachers who have taught learners coming from different socio-cultural and racial backgrounds. The main research question that this paper attempts to answer is: What are the experiences of teachers regarding the medium of instruction in a multicultural classroom?

\section{Research Methodology}

A qualitative research approach was adopted for the larger study from which this paper was extracted. Creswell and Creswell (2017) maintained that qualitative studies are meant to explore a variety of dimensions of the social world. In such studies, participants are often asked open-ended questions (Denzin \& Lincoln, 2008), which allows them to freely express themselves. This approach allowed the participants to elaborately discuss the 'how' and 'why' questions of teaching and learning in a multicultural classroom. A case study design was used and its purpose, according to Cohen and Crabtree (2006), is to use a variety of data sources for the exploration of a phenomenon. In the case of the broader study, the views of teachers were sought to understand their experiences in the language used in a multicultural classroom.

Data were collected from a sample of 18 participants from two urban high schools from Chris Hani West District of the Eastern Cape, South Africa. The reason for 
choosing these two urban schools was that learners were from different sociocultural and racial backgrounds. Another reason for this choice of urban schools was because of their enrolment of a large number of immigrant learners, reflective of the racial and ethnic diversity of the schools. An equal number of teachers, nine from each school, were purposefully selected for the study, and the face-to-face in-depth interview method of data collection was used. Using a semi-structured interview guide, data were collected on the biodata of the participants, who were all teachers, their experiments with $\mathrm{ME}$ in the classroom, their personal experiences, and their challenges, amongst other aspects. The qualitative data collected were manually processed and analyzed based on key themes.

Regarding ethical considerations, the participation in the study was voluntary. Anonymity and confidentiality were strictly adhered to during the data collection and analysis as well as dissemination. The participants also signed informed consent letters in which the objectives of the study and how ethical issues would be addressed were detailed. Participants' consent was also sought to audio-record the interviews. Ethical clearance to conduct the study was obtained from the University of Fort Hare (UFH). A request letter was written to the provincial Department of Education and District Office to seek permission for entry into the two schools. Besides this, approval was sought from the principals of the selected schools. Trustworthiness was checked throughout the research process. This entails credibility, transferability, dependability, and confirmability, which according to Williams and Morrow (2009), is the extent to which the findings are transferable to other contexts, dependable, and confirmable. Credibility was achieved through member checking, which entails participants verifying the findings as a true reflection or accurate narrative of their perspective. Credibility was also reinforced through prolonged engagement with all the participants. Furthermore, a well-managed research-inquiry audit was undertaken by ensuring that the research process and product were consistent to achieve dependability and confirmability of the data. According to Sinkovics and Alfodi (2012), dependability is the extent to which a study can be repeated with findings being consistent. Confirmability is the extent of neutrality in the research study's findings (Carcary, 2009). Therefore, during the writing process of this paper, data were quoted. In addition, audiotapes containing the raw, individual data; typed transcripts; and the final draft of the research project were stored for verification by any interested individual.

\section{Participant Demographics}

The gender distribution of the participants was deliberate (nine female and nine male participants). This was driven by the fact that, to have a comprehensive understanding of the phenomenon under study, it was vital to acquire and reflect on information about the implementation of ME amongst high school teachers from both genders. This also avoided discrimination, bias, and unnecessary assumptions on information from one gender only. This study is about diversity, where similarities and differences are recognized, including the gender of the participants. Therefore, it was necessary to offer equal opportunities to both genders. 
Concerning the ages of the participants, the majority of the teachers interviewed (12) were in the 50-59 years age range. Four were in the age range of 30-39 years and the rest (2) were in the $40-49$ years age range. This reflects that the participants were all mature teachers. All participants were qualified and trained teachers. Ten participants held a diploma in Education, six held a bachelor's degree in Education, and two held an honors degree in Education. Most of the participants (nine) had teaching experience of 1-5 years, with others (four) having worked for 6-10 years. Another four had worked for 11-15 years and only one had working experience of 20 years and above. This was a deliberate choice to ensure that there was a mixture of teachers with different levels of experience to gauge the extent of their engagement with ME. Finally, regarding race, the majority of the participants (10) were black South Africans who could write, speak, and teach in English and IsiXhosa, whereas the others (8) were Colored South Africans who were fluent in English and Afrikaans.

\section{Findings and Discussion}

The findings revealed three interesting themes that emerged from the interviews, namely:

$>$ The dominant use of English, with intermittent code-switching to IsiXhosa and Afrikaans;

$>$ Balancing the use of English with home language mostly during breaks, sporting, and cultural events not equaling ME; and

$>$ The universalism of the English language; the first (African) language as a receptor and not a creator of knowledge.

These three themes guide the discussion of the findings below.

\subsection{Theme 1: The dominant use of English, with intermittent code-switching to} IsiXhosa and Afrikaans

The participants were asked to explain which language was used in their classroom to facilitate teaching and learning. Although the participants had different views on the medium of instruction used in a multicultural classroom, the majority (12) of them reported using only English. These participants were asked why they were using English as the only medium of instruction in a multicultural setup. They maintained that this was because they were not trained in the languages of the region and were therefore unable to teach in other languages. The following are excerpts from some of the participants:

"I use English as the medium of instruction because I am not conversant with other languages of the region, including IsiXhosa. More so, I was not trained to teach in more than one language. The ME is a new policy document and the newly recruited and trained teachers should be the ones to implement it."

"I just teach in English, which is the main language. Besides, I know English and isiXhosa. These are the two languages I understand and speak, though most learners and myself will prefer their first languages, which are isiXhosa and Afrikaans." 


\begin{abstract}
"I teach in English because I am an English teacher and it is the language of instruction that is commonly used by all. Therefore, we are bound to use it as a medium of instruction and not by choice."
\end{abstract}

Whilst the majority of the participants indicated that they were using solely English as the medium of instruction in their classrooms, some participants (six) maintained that to help the struggling learners with poor English backgrounds, they sometimes had to code-switch to IsiXhosa or Afrikaans if there was a need. Some of them said they were doing so with the understanding that learners in their schools came from different socioeconomic and linguistic as well as racial backgrounds. Hence, there was a need to sometimes code-switch to help those in need of properly grasping the content of the lessons that they were delivering. One of the participants holding this view submitted that:

"Although I mostly teach in English, I sometimes code-switch to isiXhosa when I feel that the South African black learners do not understand what I want them to understand during the lesson in the classroom. However, I do not do this all the time because it excludes some learners, especially children from migrant backgrounds as well as other South African kids not coming from this region [Eastern Cape province]."

Another participant echoed the views of those who sometimes code-switch to other languages than English. She narrated that:

"I teach in English because I believe it is a unifying language. It is not easy for a teacher to be able to use all the official languages in SA to teach. I know just my isiXhosa and English. I sometimes code-switch to isiXhosa to relax. In my class, there are Afrikaans, isiXhosa, and a few isiSotho speakers, and other minority groups of learners. Therefore, once I code-switch, they feel excluded."

Most of the participants used English as medium of instruction in a multicultural classroom. Many had advanced reasons, including not having received training in other official languages or languages of the region, and hence their inability to use other languages to dispense their content. This means that ME within these urban schools seems to be a failure as the majority of the participants do not implement this policy. There is a likelihood that supervisors from the provincial Department of Education are not ensuring the implementation of this national policy of ME. English, as some participants reported, is a unifying language, and the policy also recognizes this, but, as others narrated, it is not their first language and they would have loved to teach in their first language. In other words, English is used to accommodate learners who are not from the region of the participants (Eastern Cape). For these participants, teaching in the English language fosters inclusivity, though it comes with challenges in a multicultural classroom. Presumably, this is why Nomlomo and Katiya (2018) argued that proficiency in English is the sole measure of the multilingual abilities of African-language speakers, which seems to be the controversy the participants are faced with. This is contrary to Banks and Banks's (2019) finding regarding the use of indigenous languages in teaching. Accordingly, teaching ME using English is not fair and 
does not ensure justice, especially to learners whose first and second languages are not English. Consequently, a teacher who does not use learners' first language in teaching makes learning more difficult (Vandeyar, 2010). Another participant explained that there are diverse groups of learners coming from different backgrounds and speaking different languages as first and second languages. Therefore, it becomes difficult to satisfy all the learners by teaching in their respective languages.

\subsection{Theme 2: Balancing the use of English with home language mostly during breaks, sporting, and cultural events not equaling multicultural education}

When the participants were asked how they ensured the effective implementation of ME at their schools, the majority (13) of them reported that learners were encouraged to use their local languages (Afrikaans and isiXhosa) during breaktime, sporting, and cultural events. They acknowledged, however, that this did not equal ME. They further averred that during these times, one could observe the learners interacting amongst themselves more than they would in the classroom. According to these participants, this is an indication that the learners would have preferred teachers to use their first language, in this case isiXhosa and/or Afrikaans. When asked why they encouraged learners to use their first language only during these times which are outside of the class times, the participants claimed that this was because learners must pass the first language before they are promoted to the next class. However, given the multicultural environment of the schools, participants noted that some learners whose first language (isiXhosa or Afrikaans) is not spoken in the region feel excluded and there is little they can do to help them. The following excerpts from some of the participants substantiate some of the above views:

"Learners only have the opportunity to speak their first language when they play outside and during cultural festivals. This excludes some learners, especially those who are few and do not have friends to communicate with in their language. Also, students are not promoted if they fail isiXhosa. This is another way that the school promotes the use of Xhosa, which is an advantage only for the Xhosa-speaking learners."

"We allow most learners to speak isiXhosa, Afrikaans, and English as the specific languages when they are playing and during cultural days. However, this affects other minority groups of learners and they feel unwelcome or isolated."

"Learners are not allowed to proceed to another class if they fail their home language. Therefore, understanding their home language is key, as they might not develop fully without the missing gap. They should take it seriously. However, any learner coming from another culture besides isiXhosa suffers to learn the new language just to pass the examination. This is a challenge for most new learners."

The implementation of the policy of ME seems to be in jeopardy in these schools as most of the participating teachers allow learners to use their first language only during breaktime, sporting, and cultural events. According to the participants, 
this is a way of inclusivity in the classroom. Despite this attempt at balancing the two languages (English and isiXhosa or Afrikaans), some learners whose first language is not isiXhosa or Afrikaans feel excluded and isolated. Therefore, ME is not being effectively practiced in the selected schools. Georgieva and Shehu (2017) corroborated this by maintaining that in a multicultural classroom, learners come from diverse backgrounds and speak a variety of first languages, which makes it difficult for a teacher to engage with each learner in their first language. It might therefore be difficult for a teacher to ensure the use of home language in a multicultural school. Kretzer (2019) supported this by submitting that African languages are rarely used as medium of instruction. This is because most South African schools use either English or Afrikaans as medium of instruction. Therefore, as aptly indicated, African languages are not well utilized at schools. This runs parallel to the dictates of the South African Language Policy.

The fact that learners are expected to pass their first language before proceeding to the next class is an indication of the importance of that language. However, at one of the participating schools, learners can only speak isiXhosa in class during the isiXhosa period, or during breaks, sports, and cultural events. Therefore, learners have limited time to speak their home language at school. This is worse with learners from different linguistic backgrounds. According to Section 29 of the Bill of Rights in the Constitution of South Africa, "[e]veryone has the right to receive education in the official languages of their choice in public educational institutions" (Republic of South Africa, 1996). Based on the findings in this study, it is assumed that learners are not enjoying this right. Many reasons have been advanced for this, including the inability of teachers to teach in other languages, English being seen as a global or a universal language, and the issue of learners coming from many multicultural and linguistic backgrounds (Ohyama, 2018). Thus, the policy of ME is defeated. However, Gollnick and Chinn (2012) argued that given the cultural and racial diversity of learners, integration of diversity education into the curriculum will help educators understand the differences between learners to effectively implement ME. Demir and Yurdakul (2015, p. 3653) explained that "ME is based on the principles of social justice, educational equity, critical pedagogy, and commitment to providing educational experiences that involve all". Yang and Montgomery (2013) maintained that the presence of different ethnic and cultural groups within specific learning settings does not imply the existence of ME. Similarly, Phahlamohlaka (2017) argued that ME is a complicated concept with various dimensions, and teachers usually emphasize and focus on a single dimension - language.

\subsection{Theme 3: Universalism of English; the first (African) language as a receptor and not a creator of knowledge}

The findings showed that, alongside other reasons reported earlier in this paper, most of the participants preferred English as a teaching language not because they liked it, but due to the universal nature of the English language. The participants indicated that their first language was relegated to the background and acted only as a receptor and not a creator of knowledge. The participants were asked to explain what they understood by the universalism of English and first language 
as a receptor and not a creator of knowledge as reported by some of their peers. The majority of them revealed that because English is widely spoken around the world and the fact that most books are written in English, their first languages (isiXhosa and Afrikaans) are only used to interpret what has been written. This is worsened by the fact that there are very few books written in these first languages. Therefore, the first languages are receptors and not creators of knowledge. One of the participants reported as follows:

"I would prefer to teach in my first language, which is Afrikaans, but because of other learners coming from other provinces and countries, I am bound to teach mostly in English, as it is known as the universal language. This is disadvantageous to our first language because we seem to be consumers of knowledge from English and not a creator of knowledge using our first language."

Another participant echoed the sentiment expressed by his peer above. According to him:

"We have a problem because all books are written in English and we are expected to teach in both English and our first language [isiXhosa] and this is almost impossible as a teacher needs to read in English and interpret in isiXhosa before teaching learners. We were not taught to teach in multiple languages. The government wakes up and comes up with policies that cannot be implemented effectively. How do you expect a teacher to know all the eleven official languages in South Africa and be able to use them all in a classroom because of learners coming from these 11 regions?"

The findings indicated that the majority of the participants make use of the English language because it is universal and most people understand it. Because of the universalism of the English language, African first languages are not well developed to enhance knowledge creation through writing and other knowledge-creation modes. Although the Constitution of South Africa allows for the official use of all eleven languages, the majority are still in the rudimentary stage of development. As such, there would be little or no writings of a high standard in these languages. Therefore, it becomes a challenge to successfully use them as teaching languages. In South Africa, the problem of African first languages was created by the apartheid schooling system that was created to unjustly uplift white people whilst marginalizing other, different groups (Vandeyar, 2010). Hence, white South Africans could obtain a quality education that would ensure that they were recruited into higher positions, which maintained their political, economic, and social status at the expense of other groups, subsequently leading to education inequalities. Educational policies for indigenous-culture and -language support during the apartheid era lacked a comprehensive aspect of acknowledging language rights, which led to the neglect of the African languages (Bianco, 2016). This has made these languages to be mere receptors of knowledge without the capabilities to create knowledge like other developed languages. Machaisa (2014) noted that teacher education programs and qualifications do not prepare teachers for a diversified school system, and this is the view that was held by most of the participants of this study. 


\section{Conclusion and Recommendations}

Though ME is a national policy aimed at giving equal educational opportunities to learners irrespective of their socioeconomic, racial, and linguistic backgrounds, the English language remains the predominant medium of instruction at most schools because of its universalism. The use of the English language has also been seen as leaving African languages as simple receptors of knowledge and not being able to create knowledge. Therefore, when it comes to creating knowledge that can be useful within the African context and worldwide, these languages are relegated to the background. The Constitution of the Republic of South Africa's Bill of Rights, which gives learners the right to be taught in their first language, is flouted, and rightly so, because no teacher can teach using all 11 languages of the country in a multicultural classroom in case there are learners from all the regions. As the participants reported, many of the teachers in the Eastern Cape province of South Africa can teach only in English and either isiXhosa or Afrikaans. More so, their training did not embody metalinguistic training, hence the incapacity to teach effectively in a multicultural classroom. However, in an attempt to come across as helping academically struggling students and implementing ME, some participants sometimes code-switch to IsiXhosa and/or Afrikaans if needs be. In addition, learners are encouraged to speak their first language during sports, breaks, and cultural events. Nonetheless, this does not equate to the ME put in place by the government to include all learners. Attempts at balancing the use of the English language and first languages have been criticized for being exclusive of learners whose first language is not used by the teachers. Therefore, the cycle of blame and criticism goes on. Since it is difficult to teach in multiple languages, it is recommended that the country could be zoned and that teachers, during their training, could be taught the major languages of these zoned areas. The maximum number of languages could be set at two, excluding the English language.

\section{References}

Banks, J. A. (2008). An introduction to multicultural education (4th ed.). Allyn and Bacon.

Banks, J. A., \& Banks, C. A. M. (Eds.). (2019). Multicultural education: Issues and perspectives. (10 th ed.). John Wiley \& Sons.

Bianco, L. J. (2016). Learning from difference. In L. J. Bianco, \& A. Bal (Eds.), Learning from difference: Comparative accounts of multicultural education: Multilingual Education Book Series, (Vol 16; pp. 221-227). Springer. https://doi.org/10.1007/978-3-319-26880-4_11

Bitzer, E., \& Botha, N. (Eds.). (2011). Curriculum inquiry in South African higher education: Some scholarly affirmations and challenges. African Sun Media.

BusinessTech. (2019, November 3). The big changes coming to South African schools. https:// businesstech.co.za/news/government/350805/the-big-changescoming-to-south-african-schools/

Carcary, M. (2009). The research audit trial: Enhancing trustworthiness in qualitative inquiry. Electronic Journal of Business Research Methods, 7(1), 11-24.

Cohen, D., \& Crabtree, B. (2006). Qualitative research guidelines project. http://www.qualres.org/HomeSemi-3629.html

Creswell, J. W., \& Creswell, J. D. (2017). Research design: Qualitative, quantitative, and mixed methods approaches. Sage. 
Demir, N., \& Yurdakul, B. (2015). The examination of the required multicultural education characteristics in curriculum design. Procedia - Social and Behavioural Sciences, 174, 3651-3655. https://doi.org/10.1016/j.sbspro.2015.01.1085

Denzin, N. K., \& Lincoln, Y. S. (2008). Introduction: The discipline and practice of qualitative research. In N. K. Denzin, \& Y. S. Lincoln (Eds.), Handbook of qualitative research (4th ed.; pp. 1-20). Sage.

Du Toit, P. (1995). State building and democracy in Southern Africa: Botswana, Zimbabwe, and South Africa. US Institute of Peace Press.

Gay, G. (1992). The state of multicultural education in the United States: Beyond multicultural education. International Perspectives, 41-65.

Georgieva, G. D., \& Shehu, F. (2017). Multicultural and intercultural raising and education for the children of preschool age in Republic of Macedonia. Research in Physical Education, Sport \& Health, 6(2), 27-29.

Gollnick, D. M., \& Chinn, P. C. (2012). Multicultural education in a pluralistic society. Pearson Education.

Holm, G., \& Zilliacus, H. (2009). Multicultural education and intercultural education: Is there a difference? In M. Talib, J. Loima, H. Paavola, \& S Patrikainen (Eds.), Dialogs on Diversity and Global Education (pp. 11-28). Peter Lang.

Hooijer, E., \& Fourie, J. (2009). Teacher's perspective of multilingual classrooms in a South African school. Education as Change, 13(1), 135-151. https://doi.org/10.1080/16823200902943304

Howe, E. R. (2014). A narrative of teacher education in Canada: Multiculturalism, technology, bridging theory and practice. Journal of Education for Teaching, 40(5), 588-599. https:/ / doi.org/10.1080/02607476.2014.956540

Husén, T., \& Opper, S. (Eds.). (2014, August 2-3). Multicultural and multilingual education in immigrant countries. Proceedings of an International Symposium. Wenner-Gren Center, Stockholm, Sweden.

Kamp, A., \& Mansouri, F. (2010). Constructing inclusive education in a neo-liberal context: Promoting inclusion of Arab-Australian learners in an Australian context. British Educational Research Journal, 36(5), 733-744. https:// doi.org/10.1080/01411920903142958

Kretzer, M. M. (2019). South African teachers switch languages in class: Why policy should follow. https://theconversation.com/south-african-teachers-switch-languagesin-class-why-policy-should-follow-122087.

Machaisa, P. R. (2014). School integration in South African multicultural schools: Policy challenges. Mediterranean Journal of Social Sciences, 5(23), 1590-1598. https://doi.org/10.5901/mjss.2014.v5n23p1590

Meier, C., \& Hartell, C. (2009). Handling cultural diversity in education in South Africa. SA-EDUC Journal, 6(2), 180-192.

Mickelson, R. A., \& Nkomo, M. (2012). Integrated schooling, life course outcomes, and social cohesion in multi-ethnic democratic societies. Review of Research in Education, 36(1), 197-238. https:// doi.org/10.3102/0091732X11422667

Nieto, S. (2002). Language, culture, and teaching: Critical perspectives for a new century. Lawrence Erlbaum Associates.

Nieto, S. (2009). Language, culture, and teaching: Critical perspectives. Routledge.

Nomlomo, V., \& Katiya, M. (2018). Multilingualism and (bi)literacy development for epistemological access: Exploring students experience in the use of multilingual glossaries at a South African university. Educational Research for Social Change (ERCS), 7(1), 77-93. http://dx.doi.org/10.17159/2221-4070/2018/v7i1a6 
Ohyama, M. (2018). Japanese mother tongue program in an international school: A case study [Doctoral dissertation]. Fordham University, Fordham, USA.

Phahlamohlaka, T. (2017). Challenges of inclusive education in multicultural public primary schools [Doctoral dissertation]. University of Pretoria, Pretoria, South Africa.

Portera, A. (2010). Intercultural and multicultural education: Epistemological and semantic aspects. In A. Portera (Ed.), Intercultural and multicultural education (pp. 26-44). Routledge.

Price, P. A. (2012). Multicultural and diversity education in the globalised classroom in Australia [Master's thesis]. University of Melbourne, Melbourne, Australia.

Republic of South Africa. (1996). The Constitution of the Republic of South Africa (108 of 1996). Government Printers.

Robinson, M. (2003). Teacher education policy in South Africa: The voice of teacher educators. Journal of Education for Teaching, 29(1), 19-34. https:// doi.org/10.1080/0260747022000057954

Rubagumya, C. M. (2010). English-medium primary schools in Tanzania: A new "linguistic market" in education? In C. M. Rubagumya (Ed.), Language of instruction in Tanzania and South Africa: Highlights from a project (pp. 43-59). Brill Sense Publisher. https://doi.org/10.1163/9789460912221_005

Sinkovics, R. R., \& Alfoldi, E. A. (2012). Progressive focusing and trustworthiness in qualitative research. Management International Review, 52(6), 817-845. https://doi.org/10.1007/s11575-012-0140-5

Syed, K. (2010). Canadian educators' narratives of teaching multicultural education. International Journal of Canadian Studies/Revue Internationale d'étudescanadiennes, 42, 255-269. https:// doi.org/10.7202/1002181ar

Vandeyar, S. (2010). Educational and socio-cultural experiences of immigrant students in South African schools. Education Inquiry, 1(4), 347-365. https://doi.org/10.3402/edui.v1i4.21950

Williams, E. N., \& Morrow, S. L. (2009). Achieving trustworthiness in qualitative research: A pan-paradigmatic perspective. Psychotherapy Research, 19(4-5), 576-582. https://doi.org/10.1080/10503300802702113

Wright, C. (2018). Race relations in the primary school. Routledge.

Wright, H. K., Singh, M., \& Race, R. (2012). Multiculturalism and multicultural education. In H. K. Wright, M. Singh, \& R. Race. (Eds.). Precarious international multicultural education (pp. 3-13). Brill Sense Publisher.

Yang, Y., \& Montgomery, D. (2013). Gaps or bridges in multicultural teacher education: AQ study of attitudes toward student diversity. Teaching and Teacher Education, 30, 27-37. https://doi.org/10.1016/j.tate.2012.10.003 